\title{
Bridging Deep Chasms: The Soviet Third Direction in Aleksei Rybnikov's Rock Opera The Star and Death of Joaquin Murieta
}

\begin{abstract}
Alexandra Grabarchuk
\section{Introduction}

Soviet rock opera was an anomaly among official, state-approved music for at least two reasons. First, it clearly borrowed from "bourgeois" Western sources - even more so than regular Soviet popular music, generally called estrada.$^{62}$ While the latter ranged in ideological conformity from the pro-Soviet civic songs of Aleksandra Pakhmutova to the apolitical and progressively tinged concept albums of David Tukhmanov, rock opera owed its very existence to such Western models as Jesus Christ Superstar ${ }^{63}$ Yet that wasn't the only bold characteristic of this genre. Another - and potentially even more significant process elucidated through examining Soviet rock opera is an unprecedented mixing of academic music and estrada in what the Composers' Union retrospectively called the “Third Direction.” In 2005, Ukrainian scholars I. Stetsiuk and M. Abakumov described the Third Direction as having roots in "several tendencies in academic Eastern European music of the 1950s to the 1980s, including cinematic and electronic music." ${ }^{64}$ This article will argue that Soviet rock opera was allowed to exist and evolve in part because it was another prime example of this "optimization between serious and light music." 65

62 Borrowed from the French estrade, the term literally means "small stage." Refers to cabaret, circus, popular music, and other small-scale forms of art intended to be performed on stage. For further discussion of Soviet estrada, see Alexandra Grabarchuk, "The Soundtrack of Stagnation: Paradoxes within Soviet Rock and Pop of the 1970s," (Ph.D. diss., UCLA, 2015).

63 A detailed account of JCSS circulating in composers' circles can be found in Peter J. Schmelz, "From Scriabin to Pink Floyd: The ANS Synthesizer and the Politics of Soviet Music between Thaw and Stagnation," Sound Commitments: Avant-Garde Music and the Sixties, ed. Robert Adlington (Oxford: Oxford University Press, 2009), 254-276.

${ }_{64}$ I. O. Stetsiuk \& M. A. Abakumov, "Tret'e napravlenie" i kinomuzyka Eduarda Artem'eva (Kiev: Ukraine National Musical Academy, 2005), 8.

65 Ibid.
\end{abstract}


Although estrada also engaged with classical forms (see David Tukhmanov's 1975 album On the Wave of my Memory for both aural and visual examples), the union of opera and rock music had previously neither been recognized nor lauded in an official capacity. With rock opera, just as with film or other collaborative art forms that rely heavily on institutionalized support, nationally funded theaters and artists needed the backing of government organs in order to produce any large-scale spectacle. The fact that such backing, however conditional or fraught, was found in the Soviet 1970s is a phenomenon worth exploring; it speaks to the peculiar flexibility of a Soviet aesthetic. This article will briefly touch upon the genesis of rock opera in the Soviet Union, and then examine the production of one of the first rock operas in the USSR -Aleksei Rybnikov's The Star and Death of Joaquin Murieta (Звезда и смерть Хоакина Мурьеты, 1976). Through examining the role of composer - the auteur of the Third Direction - I will argue that the transposition of rock music to the stage helped to improve its status in the Soviet Union, where theater was prized for its educational and artistic potentials. ${ }^{66}$

The term "Third Direction" was coined in the 1980s, toward the very end of the period it describes. Various sources give conflicting information on which composer used it first (Rodion Shchedrin and Vladimir Dashkevich are just two of the names mentioned as possible progenitors of the phrase). As it so often happens, the terminology began appearing only when the movement itself was in full swing, "uniting the gestures, technology, and aesthetics of serious, classical contemporary music on the one hand, and the accessibility, simplicity, and unpretentiousness of light music that was meant for purposes of entertainment, and even more precisely - commerce - on the other." ${ }^{67}$ This term soon started appearing in musical publications, lent its name to a theater studio, and ultimately engendered a Third Direction creative laboratory within the Composers' Union. ${ }^{68}$

The goal of this movement was not only to bring together diverging aesthetics, but perhaps even more importantly, to reconcile "two almost feuding audiences who were fiercely antagonizing one another." ${ }^{69}$ Russian-born ethnomusicologist Izaliy Zemtskovskiy discerned qualities such as stylistic variability, a multiplicity of sources, and a tendency toward theatricality as intrinsic to the Third Direction philosophy. ${ }^{70}$ It is the latter, "thespian" characteristic that enabled rock opera to flourish in the Soviet Union under this movement's aegis. The popularity of this aesthetic trend is partly attributable to "a well-

66 The notion of "theatricalization" of music is common in Russia; in 2005, it was even addressed in the realm of popular song in O. Deviatova's Teatralizatsiya pesni v otechestvennoi massovoi kul'ture poslednei treti XX veka (Ph.D. dissertation, Ural State University, 2005).

67 Rodion Shchedrin, "Nepovtorimost' talanta i lichnosti," in Anatoliy Tsuker, Mikael Tariverdiev (Moscow: Sovetskiy kompozitor, 1985), 87.

68 "Tret'e napravlenie: chto eto? Zachem? 'za' i 'protiv'..." Sovetskaia muzyka 1 (1990): 22-23.

69 Anatoliy Tsuker, Mikael Tariverdiev, (Moscow: Soviet Composer, 1985), 6.

70 Izaliy Zemtsovskiy, “I. Egikov,” in Kompozitory moskvy 3, (Moscow: Sovetskiy kompozitor, 1988), 63. 
chosen metaphor, rather than [to] any theoretical distinction." ${ }^{71}$ A somewhat vague attribution, the deliberately imprecise talk of a "third way" enabled musical hybridizations, chief among them the rock opera and the rock ballet. It is among this company that we find the names most frequently associated with the Third Direction: Aleksei Rybnikov, Eduard Artem'ev, and the composer of the USSR's first rock opera, Aleksandr Zhurbin.

\section{The Song of Orpheus}

Like many estrada songwriters in the Soviet Union, Zhurbin was trained and worked in "academic" genres, writing symphonies and concertos, as well as working in more contemporary and popular styles. In the late 1960s, after graduating with honors from the Tashkent State Conservatory's cello studio, he garnered a $\mathrm{PhD}$ in musicology from the Leningrad Conservatory with a dissertation on Mahler. ${ }^{72}$ In this sense, he was well equipped to bring rock music into the opera hall at this opportune moment. Soviet musicians and publishers had been "worried by the deep chasm between music designed for entertainment and serious music" since the Fourth Congress of the Union of Composers in $1968 .^{73}$

A. M. Tsuker's 1993 book-length study on this tension, suitably entitled Both Rock and Symphony..., distinguishes between classical and commercial, popular modes in a telling fashion. Rock is described and dealt with as a mere "lifestyle," whereas a symphony is deemed to be a formal achievement. This subjective and problematic generalization nonetheless helps us to understand the often incompatible discourses or debates within the Soviet Union regarding "light music.” Much of Tsuker's book is therefore dedicated to a possible synthesis of mass and academic musical enterprise, citing rock opera somewhat surprisingly - as a possible mélange of two opposites. Although other Soviet composers followed this path and composed rock operas, Aleksandr Zhurbin would be the first.

In 1973, he became involved with the Vocal-Instrumental Ensemble The Singing Guitars (Поющие гитары), setting Russian Futurist or avant-garde poetry of the early twentieth century to estrada songs. ${ }^{74}$ By that time, however, British rock opera Jesus Christ

\footnotetext{
Anatoliy Tsuker, Both Rock and Symphony... (Moscow: Kompozitor, 1993), 44.

72 “Biografia," Kompozitor Aleksandr Zhurbin: Ofitsial'nyi sait (2005). <http://www.alexanderzhurbin. $\mathrm{ru} /$ content/biografy.php>.

73 Tsuker, Both Rock and Symphony..., 4.

74 For Russian accounts of the Vocal-Instrumental Ensemble (VIA) phenomenon, see V. K. Yashkin's Vokal'no-Instrumental'nye Ansambli (Moscow: Znanie, 1980); B. P. Sokolovskiy's Samodeyatel'nye VIA i diskoteki (Moskva: Profizdat, 1987); and V. Shchëlkin \& S. Frolov's Legendy VIA, (Moscow: Grifon, 2007). A fascinating description from within the VIA scene itself, Ariel' frontman Valeriy Yarushin's autobiography has also proven very informational: V. Yarushin, Sud'ba po imeni 'Ariel" (Moscow: Russkaia nov', 2005).
} 
Fig. 1: Aleksandr Zhurbin in 2010

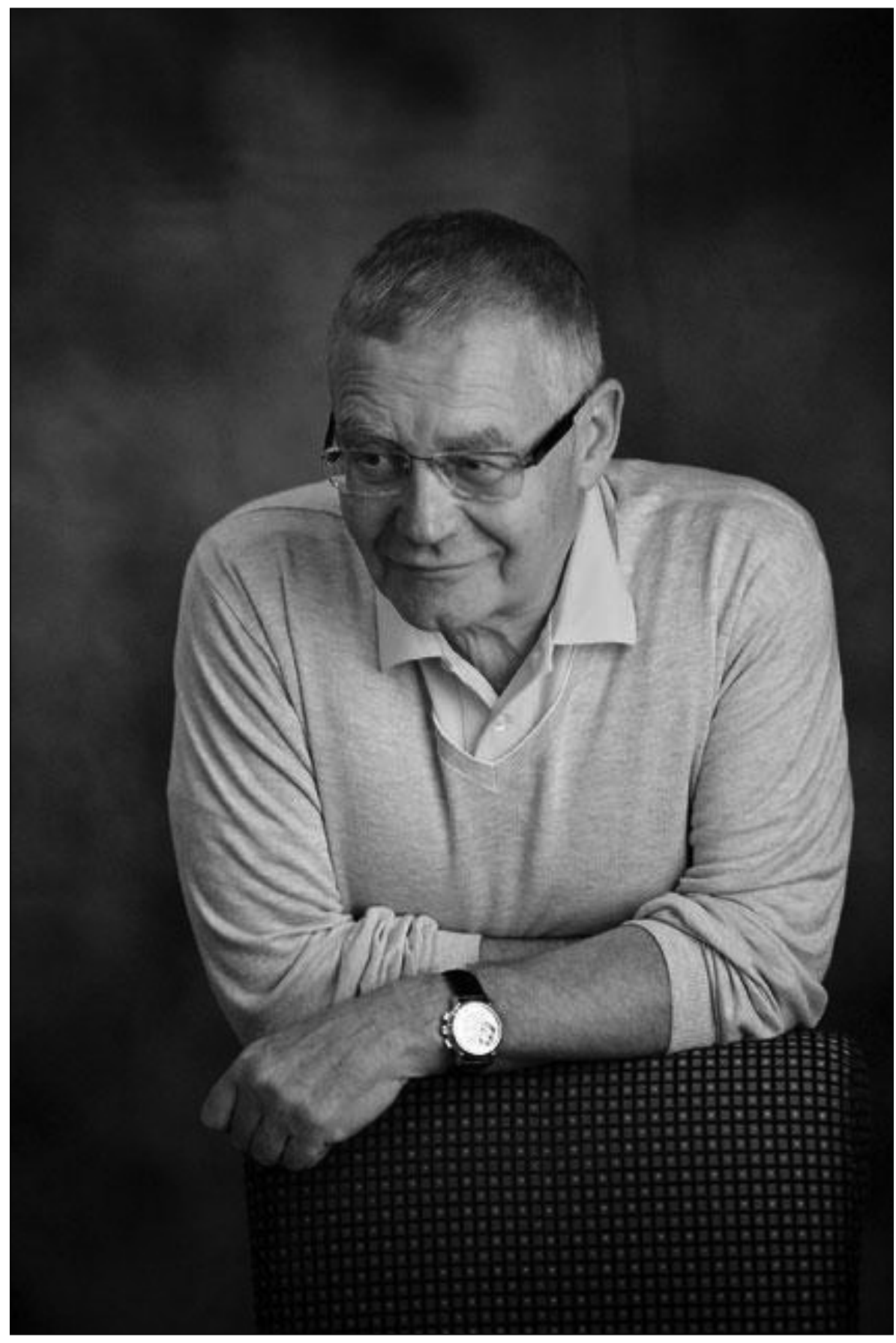


Superstar was already being widely circulated within knowing circles of Soviet musicians. ${ }^{75}$ Head of the Leningrad Union of Composers Andrei Petrov - who would later use his pull to aid Orpheus' premiere - brought a recording of the Webber musical back to the USSR and organized a listening session for other composers. Zhurbin found the British rock opera immediately compelling, and even began to learn English after his exposure to it. ${ }^{76}$ In dialogue with front-man and guitarist of The Singing Guitars, Anatoliy Vasil'ev, the two men agreed on their mutual desire to see something similar done in the USSR. In 1974, Orpheus and Eurydice - with his score and a libretto by playwright Yuriy Dimitrin - was presented to the band. ${ }^{77}$

After some changes in personnel, the producers found their Orpheus in the figure of Al'bert "Alik" Asadullin - a young architect from Tatarstan who had already gained a reputation as "the best amateur rock singer among faculty music groups" upon his arrival in Leningrad. ${ }^{78}$ Zhurbin and Vasil'ev convinced Asadullin to join The Singing Guitars, and for the next five years he toured with the group. Eurydice was found right within The Singing Guitars in Irina Ponarovskaia, daughter of famous jazz musician Vitaliy Ponarovskiy. ${ }^{79}$

Fig. 2: Irina Ponarovskaia and Al'bert Asadullin as Eurydice and Orpheus

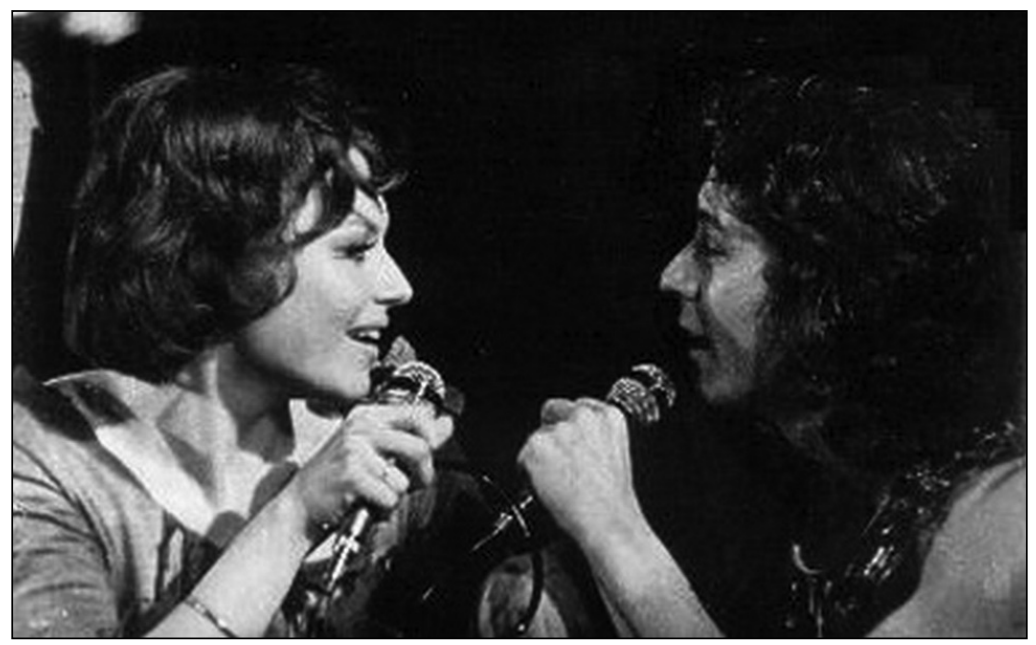

75 See Peter J. Schmelz, "'Crucified on the Cross of Mass Culture': Late Soviet Genre Politics in Alexander Zhurbin's Rock Opera Orpheus and Eurydice," Journal of Musicological Research 28.1 (2009): 61-87 for an account of Soviet reception of Webber's musical, and its effect on Zhurbin's rock opera. Despite its taboo themes, stagings of the work were not consistently banned, and it was widely heard and even performed by groups such as the jazz-rock band Arsenal. Ibid., 69.

77 “Orfei i Evridika," Kul'turnyi sloi, 5-yi kanal, TRK St. Petersburg, 10 May 2009. <http://www.5-tv. $\mathrm{ru} / \mathrm{video} / 502622 />$.

78 Valery Shchëlkin and Sergey Frolov, Legendy VIA (Moscow: Grifon, 2007), 28.

79 For more biographical details on Irina Ponarovskaia, see her site: http://www.iponarovskaya.ru/bio.php. 
Orpheus and Eurydice premiered in the summer of 1975 at the Leningrad Estrada Theater (now the Raikin Estrada Theater in St. Petersburg). It was originally marketed as a Song-opera from the German der Song - because the term "rock" caused a predictable problem within the Soviet Ministry of Culture. ${ }^{80}$ A rock aesthetic was dampened somewhat, or made more palatable with allusions to Brechtian theatre, "where songs are woven into the fabric of the narrative, summarizing and ultimately acting as a moral injunction." ${ }^{11}$ The issue was then complicated by other concerns:

The theatrical term der Song, originating with the German playwright Berthold Brecht, needs to be understood not just as song, but as a [specific form of] "song" from the author, during which the actors turn to the audience, breaking the fourth wall. This [combination of techniques] both illuminates the author's subtext and provides commentary for the events on stage. This Brechtian principle found its reflection in Orpheus. ${ }^{82}$

According to librettist Yuriy Dimitrin, once censors were informed of this connection to the work of the "anti-Fascist" Brecht, the production could then be considered an artistic success. ${ }^{83}$ Although Brecht may have been chosen as a specific figure with which to forward this idea, Zhurbin cites other theatrical genres, including ancient Greece, as containing the "rock opera" concept. ${ }^{84}$ In this way, rock opera was born in the Soviet Union under the cover of more acceptable art forms. Despite any sleight-of-hand, however, the show's immense popularity would make any such quibbling a moot issue. Subsequent projects in the same style were widely referred to - in more open terms - as rok-opery.

Zhurbin himself has been inconsistent over the years in labeling the piece's genre. In retrospect from the twenty-first century, he considers rock opera as a subgenre of the musical - in much the same way as Jesus Christ Superstar is considered an example of both today. In a 2011 article for Izvestiya [News], the composer expressed indignation that another piece, Solomennaia shliapka [The Straw Hat] (1974) - a "cute vaudeville film, yet without any distinguishing characteristics" had been labelled "the first Soviet musical." 85 Yet initially, Zhurbin was unwilling to refer to Orpheus and Eurydice as either a musical or a rock opera. From our vantage point forty years hence, Zhurbin's production is simultaneously a representative of all of the debated forms - a "Song-opera," a rock opera, and a musical. However, it wasn't until Raimond Pauls' 1976 Sister Carrie, produced in

80 Peter Pchelintsev, "Edintsvennyi v Rossii,” Rock-opera.ru. n.d. <http://rock-opera.ru/about/abouttheatre.html>.

81

82 Valery Iashkin, ““Poiyushchie gitary.” Sovetskaia estrada i tsïrk 3 (March 1978), 19.

83 "Orfei i Evridika."

84 Aleksandr Zhurbin, Orfei, Evridika, i ya (Moscow: Eksmo, 2006), 475.

85 Aleksandr Zhurbin, “Tezisy o muzykle v Rossii,” Izvestiya (8 May 2011). 
the somewhat more liberal Baltics, that a Soviet composer willingly and openly labelled his or her work with that title. ${ }^{86}$

One stepping-stone between censorship and acceptance was another form of classical narrative: myth. The choice of ancient Greek myth as subject for the USSR's first rock opera was clearly a legitimizing act on the part of its producers. One critic wrote: "This is a show about love - love that helps an artist keep his soul alive. Not about the kind of love we frequently hear of in estrada: assertive, optimistic, and aggressive - even when it seems to be unhappy. Here, however, we have a genuinely lofty and sacrificial love." ${ }^{87}$ This idea of thematic purity was a purposeful choice on the composer's part, who pronounced the rock opera's chosen topic "entirely chaste and beautiful." 88 Zhurbin's experiment, as it was labelled in press reviews of the time, contained echoes of another canonical experiment, as it were: Monteverdi's 1607 L'Orfeo. The early Baroque favola in musica, one of the first surviving operas, moved theatrical music beyond any traditional intermedio position (i.e., between the acts of a play) and into a complete, self-contained musical drama. In some ways, Zhurbin's and Monteverdi's works have more in common than the operatic canon (including Gluck's Orfeo) that lies between them chronologically: both were composed at transitional points in European history, both employed instrumental groups that had the freedom to improvise (Zhurbin's score speaks of "adlibbed numbers in the style of the latest hits"), and both had a librettist who adapted to the sociopolitical pressures of the times. ${ }^{89}$

In Zhurbin's case, the incorporation of a rock group and contemporary lyrics from Yuriy Dimitrin meant the libretto had to be set in modern times. Subsequently the core myth was updated within the context of a rock singing contest. This allowed rock music to exist within the new opera, but to be safely contained within this plot device. Tsuker sums it up: "Rock in Orpheus occupies a sufficiently localized, albeit dramaturgically important place." ${ }^{90}$ Other pieces in the opera, as Peter Schmelz notes, were more "indebted to the aesthetics of art song, or more likely the Russian romance, than to the pop tunes that were Lloyd Webber's models." ${ }^{91}$ Only some formal schemas of the Greek plot remain: the love of its titular characters, together with their subsequent separations and reunions. The original myth ends gruesomely, with Eurydice taken back to Hades and Orpheus torn apart by Maenads, frenzied followers of Dionysus. Monteverdi's librettist, Alessandro Striggio, shies away from Orfeo's death - instead having the Maenads berate the hero - but leaves his destiny uncertain. In Monteverdi's 1609 score, however, a semi-happy ending prevails

\footnotetext{
86 See Grabarchuk (2015) for a discussion of Pauls' musical, and for an analysis of what other factors might have enabled him to do so.

87 Yuly Smelkov, “Liuboviu rozhdaetsya pesnya,” Komsomol'skaya pravda (29 August 1981).

88 Zhurbin, Orfei, Evridika, i ya, 467.

89 Tsuker, 186.

90 Ibid., 178.

91 Schmelz, 73. See Schmelz's article for a deeper analysis of musical genre and stylistic distinctions in Zhurbin's rock opera.
} 
as Orpheus is borne up to heaven by Apollo, who encourages him to see Eurydice's likeness in the stars..$^{92}$ In Dimitrin's tale, something similar takes place at the end of the opera, as her voice remains with Orpheus as if to represent their eternal spiritual union, while a new couple takes the stage to symbolize a tale of eternal love.

Zhurbin and Dimitrin's musical - despite any hesitant, lukewarm reactions from the press - enjoyed tremendous popularity. In 2003, it entered the Guinness Book of World Records as the longest-running original cast musical (at that time, 2,350 performances had been staged in eight different productions). ${ }^{93}$ Even in 1976, despite never having been performed abroad, it garnered the British Musical Award from industry publication Music Week. ${ }^{94}$ Looking back on their hard work and surprising success, both composer and librettist reminisce about the burden of daily performances:

That had never happened in Russia before. For plays or musicals to run every day was unheard of. Then we started touring. We were sold out for two, even three months. You couldn't even get a friend or your relatives into the hall. But even the show's fantastic popularity couldn't absolve it of "ideological sedition." 95

The opera's staging - despite that official grumbling in high places - got off to a remarkably smooth start, for which Aleksandr Zhurbin could thank aforementioned fellow composer Andrei Petrov. Zhurbin's friend and colleague had intervened on the show's behalf during a meeting:

The artistic council convened. Andrei Pavlovich [Petrov], an experienced diplomat, thought that everything depended on who spoke first. He immediately took the floor and said: "I consider this a huge success. It is a colossal step forward. Our socialist culture has achieved new dimensions." Then he started saying things no one could oppose, especially since he was a member of the Regional Committee [of the Communist Party], chairman of the Composers' Union, and so on. After a few of Petrov's comments, I could already see that the officials were somehow deflated. They had wanted to ban the show. [Thanks to Petrov, however], it turned out it to be nothing more than a love story without anything anti-Soviet. And so they [the high-ranking bureaucrats] resentfully told us that we had permission. ${ }^{96}$

Some problems, however, proved rather stubborn. At a later date, the opera was - again denounced, this time as "ideologically vicious and aesthetically helpless." ${ }^{97}$ Librettist Dimitrin recalls getting a phone call from a ministry connection warning of a commission

\footnotetext{
92 Mark Ringer, Opera's First Master: The Musical Dramas of Claudio Monteverdi (Newark, N. J.: Amadeus Press, 2006), 39-40.

93 Irina Vorob'eva and Artur Gladyshev, Velikie miuzikly mira (Moscow: Olma-Press, 2002), 400.

94 Ibid.

95 "Orfei i Evridika."

96 Ibid.

97 Ibid.
} 
designed to reach Leningrad and close down Orpheus. Apparently, the Russian Minister of Culture himself - Yuriy Melent'ev - had found something wrong with the piece. Yet at the last minute, Zhurbin and Vasil'ev recount in a 2009 interview, the Minister had a chat with an old friend, who happened by good fortune to be an admirer of the show. As a result, the members of the commission received last-minute instructions to support the opera upon their arrival in Leningrad. ${ }^{98}$

Fig. 3: Composer Andrei Petrov, who helped support Orpheus and Eurydice's premiere

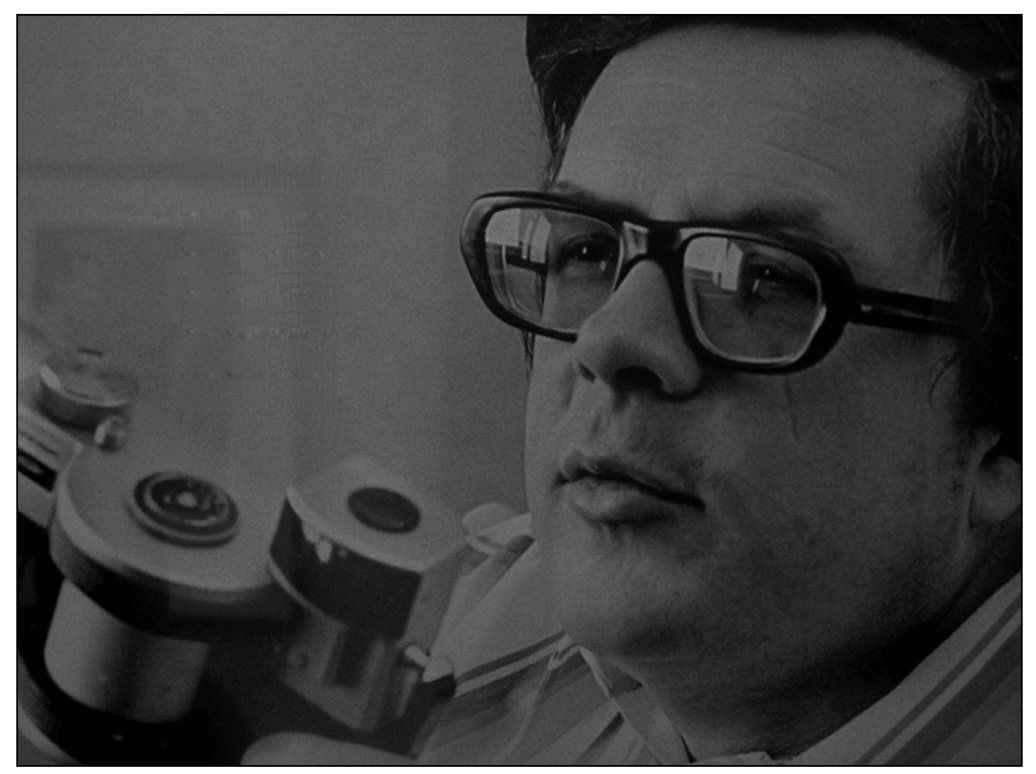

In other words, the first Soviet rock opera came into existence thanks both to a number of chance accidents within the censorship network, and huge public approval. Once official approval was begrudgingly given, the press then had to somehow justify its enormous popularity. Rhetoric was needed to echo an ideological volte-face. Newspapers' justifications frequently came in discussions of Soviet theater's power of communication, which unlike the small stage of estrada, allegedly had the capacity to both reach and deeply move observers of all ages. By way of observation, music journalist M. Provorov wrote in 1976: "The sound of an electric guitar is very pictorial, textural, and theatrical; not surprisingly, many directors have started using it in their dramas." ${ }^{99}$ Slowly yet surely in the mid-1970s, the instrumentation and performance style of the VIA were gradually considered to be in

\footnotetext{
98 Ibid.

99 M. Provorov, ““'Obratnyi put' poterian,” Iunost' 5.252 (May 1976), 108.
} 
sync with youth culture across the Soviet Union. Orpheus and Eurydice's original director Mark Rozovskiy puts it thus in his discussion of the opera's themes:

The youth lifestyle of the 1960s and '70s engendered a contemporary "musico-theatrical" form. In our show, opera's traditional form is transformed into an energetic and carnivalesque spectacle. And carnival doesn't always mean celebration. Ironic comedy and tragedy always coexist in carnival, constantly and invisibly flowing into one another. ${ }^{100}$

This genuine movement toward a Third Direction - particularly its educational potential through operatic tradition - meant that as the show went on, press reviews became more positive, acknowledging the hybridization of previously separate genres:

We still recognize the VIA ensemble's performance style; it has not changed, but rather been filled with new and more significant content... Estrada is usually called a "light" genre, although neither pathos nor civic themes are alien to it. And now, the modern estrada fan is offered shows that, although composed in this same light genre, are quite serious. That is to say, these shows not only entertain, but also offer an aesthetic education in the direct sense of the word, because for a certain youth demographic (and estrada spectators are predominantly young people), music begins with an estrada song. ${ }^{101}$

The song-opera Orpheus and Eurydice - the first such experiment on our stage - will undoubtedly acquire a noteworthy place in our country's musical theater life. It will also play its role in the creative destiny of The Singing Guitars, and - let's hope - in the education of Soviet youth, too. ${ }^{102}$

It is the elevation of popular music to the Soviet stage that allowed The Singing Guitars to "transcend their estrada past, their long-time repertoire of hits, their own selves of yesterday. And the force which elevated them was theater." ${ }^{103}$ Opera allegedly shaped and saved rock music - even though the latter style was clearly ascending and using opera to gain acceptance. The inclusion of rock within Zhurbin's project was justified by the show's large-scale impact on young audiences:

If we remember the fact that estrada is one of the most popular forms of art, and that its audience is comprised of mainly young people, then we understand that the price of Orpheus and Eurydice's success is especially high. This play invites spectators to experience thoughts and feelings to which theatergoers are rarely accustomed. ${ }^{104}$

\footnotetext{
100 Ibid., 108-109.

Yuri Klimov, “Chto na estrade?” Pravda 197 (15 July 1976): 6.

102 "Poyushchie Gitary staviat operu," Smena 173 (25 July 1975): 3.

103 Provorov, 109.

104 Smelkov.
} 
Such a perspective demonstrates the spreading "reappraisals of popular music instigated by Zhurbin's Orfeus and Eurydice." 105 The authorities and state-run media increasingly concurred with one another, and by 1980, the rock opera's creators had been given permission to record. A troublesome stage show was allowed to create a permanent, endlessly replicable document of itself. The resulting double album sold over a million copies, surviving even the demise of the group who started it all - The Singing Guitars. ${ }^{106}$ Since the fall of the Soviet Union, the show was revived in 1999 by Vladimir Podgorodinskiy, the founder of the Rock Opera Theater. This St. Petersburg (initially Leningrad) organization was founded in 1975 simultaneously with the genesis of Orpheus and Eurydice. Its mission was to serve as an "antipode to classical opera, a theater by young people - for young people." 107 The R.O.T. has, since that time, enjoyed productive relationships with contemporary Russian composers as well as established figures of the Soviet past, such as Andrei Petrov, Zhurbin's influential contemporary who helped set the rock opera on a course toward approval in the mid-1970s.

Needless to say, not everyone was convinced of the validity of combining estrada with art music. Avant-garde composer Edison Denisov expressed his displeasure with this trend in the mid-1980s: "There isn't any 'third direction!' That is a false movement which has gathered around itself people incapable of writing good estrada, jazz, or rock music. And because they can't compose any of them, they've chosen something in the middle." 108 Ticket sales and popularity, however, told a different story. Aleksandr Zhurbin's philosophy, despite these enduring hassles, would always remain more inclusive: "Some people think that rock music is something of a lower order; they insist that a serious composer would never engage with it. I think that's said out of ignorance." 109 In the same spirit, Zhurbin is remembered today as one of the first composers to endorse and work toward that elusive Third Direction. Ultimately, this opera "embodies the shifting nature of Soviet taste, both musical and otherwise, both 'official' and unofficial,' and both young and old, during the final decades of the USSR." 110 Once that door was open, others drew inspiration from Zhurbin's foray into generic synthesis - in realms where no Soviet composer had gone before.

\footnotetext{
Schmelz, 67.

106 "Orfei i Evridika."

More information about the theater can be found at http://rock-opera.ru/about.html.

108 Tatiana A. Kurysheva, Muzykal'naia zhurnalistika i muzykal'naia kritika (St. Petersburg: Vlados Press, 2007). Accessed 31 July 2015 at http://thelib.ru/books/tatyana_aleksandrovna_kurysheva/ muzykalnaya_zhurnalistika_i_muzykalnaya_kritika_uchebnoe_posobie-read.html.

109 Provorov, 109.

110 Schmelz, 67.
} 


\section{Splendor and Death}

One such fellow composer of equally intrepid interest was Aleksei Rybnikov. Born on July 17, 1945 - only a few weeks before Zhurbin - he remains a direct peer, compatriot, and product of the same cultural environment. Rybnikov was a precocious child of two creative parents, and wrote his first pieces for piano at age eight. Like many of the composers discussed so far, he attended the Moscow Conservatory and studied with Aram Khachaturian, going on to teach in the Conservatory's composition department. In 1979, he was recognized as the most popular Soviet composer of the year. ${ }^{111}$ Another classically trained member of the Third Direction, he is remembered today for his film and stage music, including the two rock operas The Star and Death of Joaquin Murieta (1976) and Juno and Avos (1979). ${ }^{112}$

Fig. 4: Aleksei Rybnikov in the studio

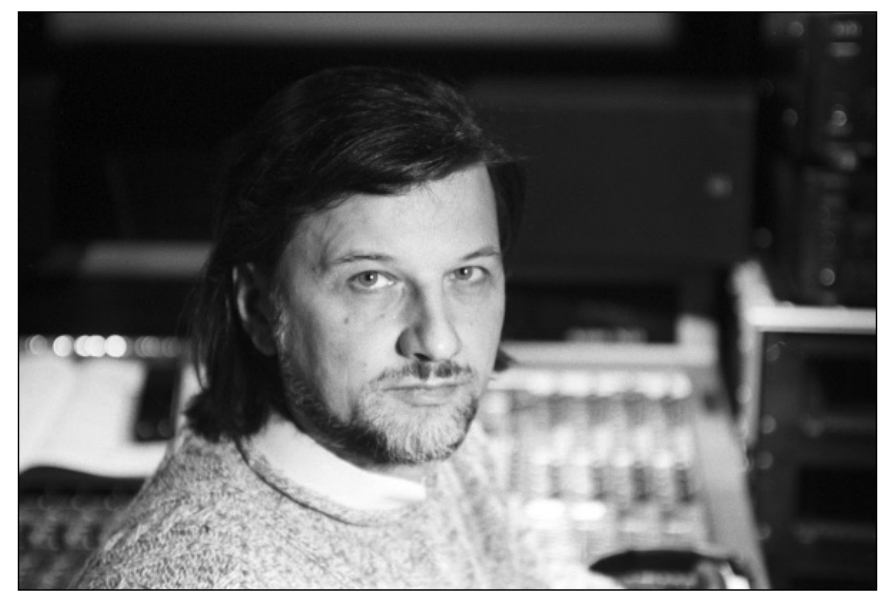

We turn now to the former, one of the very first Soviet rock operas along with Orpheus and Eurydice. Whereas Zhurbin's work was explicitly inspired by Andrew Lloyd Webber's

111 “Rybnikov Aleksei L’vovich,” Muzhdunarodnyi ob'edinënnyi biograficheskiy tsentr, n.d., accessed 7 November 2015. <http://www.biograph.ru/index.php?option=com_content\&view=article\&id=1013: rybnikoval\&catid=6:music \&Itemid=29>.

112 As Peter Schmelz mentions regarding Rybnikov's later opera: “Alexei Rybnikov's Juno and Avos (Iunona i Avos', 1981; libretto by Andrei Voznesenskiy) is often mentioned as the first instance of the genre in the USSR, although it postdates Zhurbin's composition and also postdates Rybnikov's earlier rock opera, The Splendor and Death of Joaquin Murieta (Zvezda i smert' Khoakina Mur'ety, 1976; libretto by Pablo Neruda). See S. Frederick Starr, Red and Hot: The Fate of Jazz in the Soviet Union 1917-1991, With a New Chapter on the Final Years (New York: Limelight Editions, 1994), 374 n. 78; Alexei Rybnikov, Juno \& Avos, Melodiya CD, 6000327 (1996; the back cover proclaims it as "Russia's First Rock Musical”); and Carol Pratl, “A Russian Rock Opera: 'Junon and Avos'," The Drama Review 28/2 (1984): 125-128." 
Jesus Christ Superstar and conceived within an incipient rock music environment, Joaquin was first conceived as a stage show. Film and stage director Mark Zakharov, who was appointed artistic director of the Moscow Lenkom Theater in 1973 (and still holds the position), had been urged by Vladimir Panchenko - the director of the Culture Sector of the Communist Central Committee - to stage an "ideologically flashy action show." 113 General Pinochet's recent coup d'état and the death of Chilean poet Pablo Neruda mere days after the overthrow influenced Zakharov's thinking, and he chose Neruda's 1967 poetic play - an "insurrectionary cantata" - as the basis for such an endeavor. ${ }^{114}$ The director's intention was to "somehow adapt Neruda's free verse, which is beautiful but somehow not ours." 115

For a libretto, he turned to poet Pavel Grushko, who had translated Neruda's play in 1971 for publication in the journal Foreign Literature. This introduced some major changes into the story - including altering the title from The Splendor and Death of Joaquin Murieta (Fulgor y Muerte de Joaquin Murieta) to The Star and Death of Joaquin Murieta (Звезда и смерть Хоакина Мурьеты). Grushko recounts this titular change as not posing "too much of a boon in the [original] translation of the cantata," but reports that "it really helped" when transitioning to a libretto. ${ }^{116}$ It allowed for the creation of eponymous characters of Star and Death, played respectively by the same actors who played Teresa and the perverse sideshow announcer who opens the show. The most crucial change, however, was pairing Neruda's text with the popular VIA Araks - which by this time had garnered a reputation for covering songs by Led Zeppelin, Deep Purple, and Santana. ${ }^{117}$ Other popular ensembles Rok-Atel'e and Integral joined the soundtrack of the rock opera's 1982 film version.

As for the historical figure of Joaquin Muerieta, it is entirely possible he never actually existed. Considered the Robin Hood of the California Gold Rush, Murieta - real or otherwise - captured the imagination of artists starting with the Native American novelist John Rollin Ridge in the mid-nineteenth century and continuing with Twentieth Century Fox in the late 1960s. Ridge, writing under his Cherokee name "Yellow Bird," published The Life and Adventures of Joaquín Murieta: The Celebrated California Bandit in 1854. According to Ridge scholars, this novel - the first published by a Native American, and one of the first written in California - was intended as a work of fiction, yet taken as documentary truth by historians of the time. ${ }^{118}$ Due to its mass popularity and the low social status of

113 Pavel Grushko, “'Khoakin Murieta' dvadtsat' let spustia,” Ogonëk (9 June 1996).

114 Pablo Neruda, Splendor and Death of Joaquin Murieta, trans. Ben Belitt (New York, NY: Farrar, Straus \& Giroux, Inc, 1972), viii.

115 Grushko.

116 M. Tereshchenko, "Vsë perevod, dazhe rech - s iazyka myslei,” Liudi (2 February 2002).

117 For a history of the ensemble, see their site: http://www.araks-rock.ru/story.html.

118 For more information on the Native American author, see James W. Parins, John Rolling Ridge: His Life and Works (Lincoln, NE: University of Nebraska Press, 2004). 
its author, the book suffered from widespread plagiarism, which robbed John Rollin Ridge of any deserved income - yet helped spread the tale of Joaquin Murieta.

The legendary bandit was allegedly born in northwestern Mexico and went to California to join the Gold Rush in 1849. Ridge's fictional account has Murieta and his family treated poorly by racist miners jealous of his success, who rape the hero's wife and horsewhip him. ${ }^{119}$ Other sources tell of Murieta's paramilitary band, made up of friends and relatives who illegally traded horses with Mexico and helped Murieta avenge his attackers. ${ }^{120}$ Most agree on the fact that he was as highwayman who attacked both wagon trains and settlers with his posse. In 1853, a group of California State Rangers - formed specifically to deal with Gold Country outlaw gangs - came upon Murieta's gang, the Five Joaquins, and killed him. The California State Military Museum tells of the Rangers decapitating Murieta and displaying his head throughout the state, along with the threefingered hand of an accomplice. ${ }^{121}$ Nonetheless, newspapers of the time cast aspersions on the official "identification" of the head as Murieta. ${ }^{122}$ In short, a cattle thief with that name probably lived during the 1850 s, but there is no consensus on whether he was Chilean or Mexican; an ethical Robin Hood or a manic beast. What is clear, however, is that the story was compelling to writers and readers alike.

Neruda took creative license with an already muddled tale. His 1967 play opens with a foreword describing the approach:

These pages are not concerned with confirming history or validating fantasy. On the contrary. Between the fantasy and the history of things, I have interposed my personal identity. Around it whirls a maelstrom of fire and blood, avarice, outrage, and insurrection. ${ }^{123}$

The cantata begins with a choir, telling of the renowned bandit Joaquin Murieta, a bold Chilean whose spirit haunts California to this day. We then find ourselves in the port of Valparaíso, where the aforementioned Three-Fingered Jack persuades a customs agent to come to California with them in search of gold. During the trip, Joaquin weds his beloved Teresa - although at this point in Neruda's cantata, they are only silhouettes on the stage. Upon Teresa's arrival, she is raped and then murdered by local rangers who proclaim the White race to be superior to all others. Joaquin returns home and promises revenge; from that day forth, he will live as a bandit. He is ultimately captured and beheaded. The play ends with Murieta's severed head lamenting his love, death, and the passing of time.

119 John Rollin Ridge, The Life and Adventures of Joaquin Murieta, The Celebrated California Bandit (Fresno, CA: Three Rocks Research, 2005).

120 Frank Latta, Joaquín Murrieta and His Horse Gangs (Exeter, CA: Bear State Books, 1980).

121 For more information on the California State Rangers and Murieta, see www.militarymuseum.org (under California Militia and National Guard Units, then California State Rangers).

122 “The Los Angeles Fruit Crops - The Head of Joaquin Muriatta not taken - A strange story!” The Daily Alta 4.23 (23 August 1853): 2.

123 Neruda, vii. 
Like other fictional depictions of Murieta, Neruda's grants both depth and feeling to the title character - while adding a clear authorial presence (in fact, the disembodied voice opening the prologue and narrating throughout is labelled "The Poet's Voice"). Indeed, the translator's notation highlights Neruda's presence:

The poet is constantly present in his drama of "splendor and death," meditating the occasion of his poem, appraising the morality of his hagiography of violence, vindicating the banditry of his hero, mediating, justifying, disclosing: the theophanic god-in-the-machine of his contrivance. ${ }^{124}$

In the same way, the creators of this Russian rock opera left their own indelible mark on the legend of a charismatic bandit. The pitiful story expressed in Neruda's poetry - and amplified by Aleksei Rybnikov's heavy soundtrack - became downright grim in its Soviet guise. He recalls: "I decided to do 'The Star and Death...' as symphonic rock, a combination of big symphonic form and rock rhythms." ${ }^{125}$ Much like the creators of Orpheus and Eurydice, so the composer of Joaquin Murieta was also partaking in the aesthetic and philosophical aim of the Third Direction movement.

Fig. 5: Aleksei Rybnikov ( $2^{\text {nd }}$ row, $4^{\text {th }}$ from $\left.L\right)$, director Mark Zakharov ( $2^{\text {nd }}$ row, $4^{\text {th }}$ from $R$ ), VIA Araks, and other performers

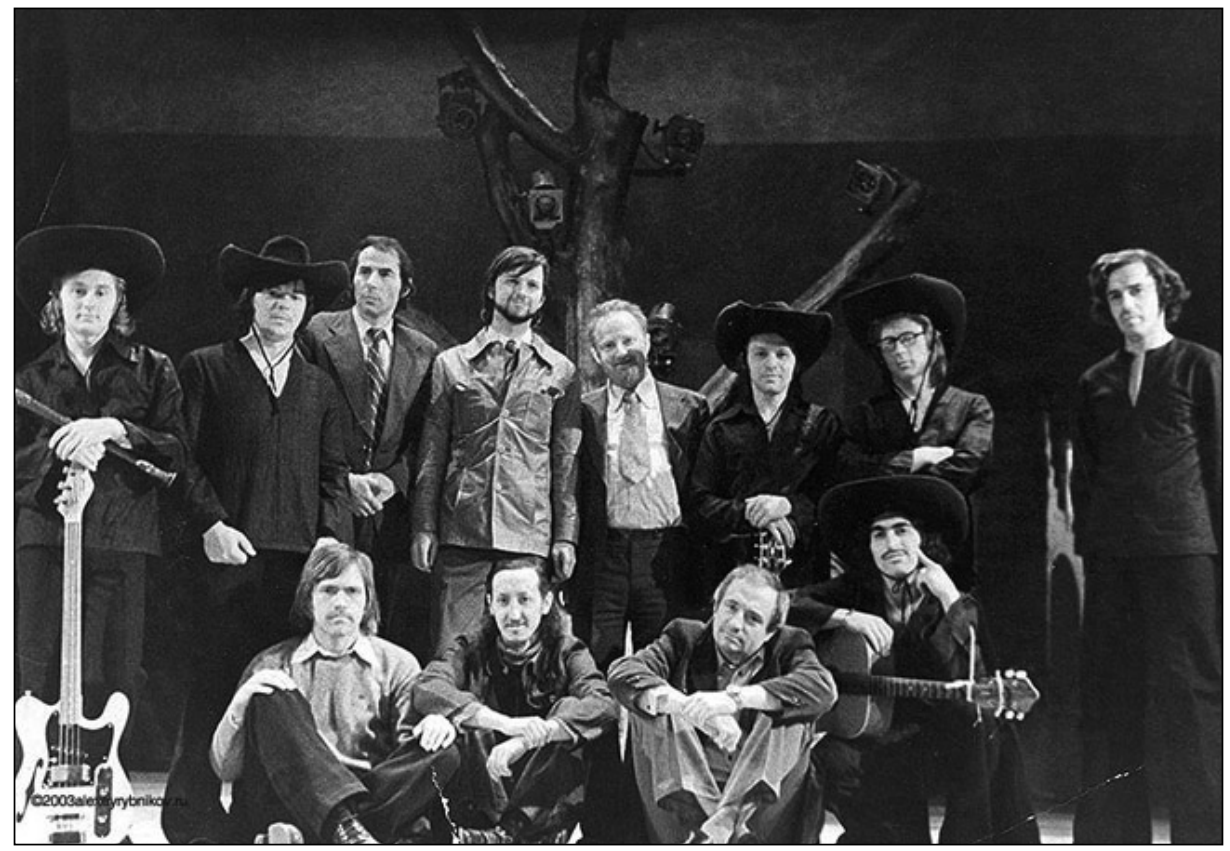

124 Neruda, xvii.

125 L. Guzeeva, “'Yunona' proshla rify na Avos'," Novaya Gazeta (9 July 2001). 
Although there were some similarities with Zhurbin's narratively contained version of rock 'n' roll, Joaquin Murieta went a little further in its embracing of rock onstage. As Peter Schmelz breaks it down:

Jesus Christ Superstar was hybrid on many levels: low/high, political/apolitical, religious/critical of religion, rock/classical, “entertainment”/“art.” Zhurbin's Orpheus and Eurydice was a diluted version of this hybridity. It was seen as provocative by its composer, its listeners, and many (but not all) Soviet officials, but its musical style was relatively orthodox for 1975, especially since it featured one of the better-known officially sponsored VIAs. ${ }^{126}$

Rybnikov's piece exhibited a less-watered down hybridity that allied it more closely with Western models such as Jesus Christ Superstar. Where Orpheus and Eurydice kept the rock aesthetic paired with "clear 'classical' signifiers" such as "the running scales that each singer performs while warming up for the contest," Joaquin Murieta expanded its range of appropriate use. ${ }^{127}$ Through an examination of musical style and narrative in this quasi-Western rock opera, I hope to demonstrate how Rybnikov continued the development of the Soviet rock opera genre - while simultaneously taking another step toward the Third Direction. ${ }^{128}$

The opera begins with a cabaret-style announcer, who advertises the spectacle of $\mathrm{Mu}$ rieta's head and the three-fingered hand of his accomplice, on display at this macabre sideshow. In the 1982 film version of the piece, the announcer's mask is stripped off to reveal the unsmiling face of Death - a visage the viewer doesn't yet recognize, but will come to associate with everything gruesome and horrible by the end of the production. ${ }^{129}$ At 1:50, the credits launch into an action theme with a serious, driving affect and instrumentation (frantic percussion reminiscent of Mitch Mitchell circa Jimi Hendrix Experience era, heavily distorted ascending electric guitar riff, intermittent brass punctuation). Such a musical opening warns of dark things to come.

A few minutes later (at 3:38), the driving assemblage of riffs lets up and melts away into what I call the "Chile theme." This style of music simultaneously indexes a folk aesthetic - complete with strummed strings, lively (although not overly wild) percussion, and a ballad feel - as well as stereotypical "South American" signifiers such as the pan flute. The Chile theme grounds any action taking place in the homeland, and also serves to call up a sense of nostalgia for home later in the opera. The Chileans' relationship to their homeland is a complex one, as witnessed by "Song of the Organ Grinder" (beginning at approximately 8:00 in the film version). This creepy, carnivalesque tune - speeding up cartoonishly as it goes - relays that "we've been taught since childhood that there is no

126 Schmelz, 84.

127 Ibid., 74.

128 For work explicitly naming Aleksei Rybnikov as one of the pioneers of the Third Direction, see Stetsiuk \& Abakumov (2005), as well as Kurysheva (2007).

129 Zvezda i smert' Khoakina Mur'ety. Dir. V. Grammatikov. Tsentral'naia kinostudia detskikh i yunosheskikh fil'mov imeni M. Gork'ogo, Yaltinskiy filial, 1981. The film can be viewed at https://www. youtube.com/watch?v=1sWIa0p4oaQ. 
country more wonderful than Chile," and lists the country's many charms, yet finishing each list by declaring that "there is no life" to be had there.

The first "diegetic" appearance of rock music, aside from the overture, comes with the appearance of the capitalistic sirens who entice the Chileans with promises of gold. This is similar to Orpheus, where Zhurbin gives "conventional rock songs, with bluesy electric guitar solos to indicate their authenticity" to the other participants of the singing contest. ${ }^{130}$ Their repetition of the word "gold" [золото] acts as a rhythmic driver and compels its listeners to pack up and head to California. When Joaquin and his friends are talking alone after this barrage, however, he does not mimic their obsession with gold, but rather sings a simple pop ode à la Andrew Lloyd Webber's "Everything's All Right" to the things that really matter - "a house by a pond...a garden with cherry trees...and roosters singing at dawn." Thus it is established from the get-go that while folk music belongs to the Chileans, and affable pop to Joaquin and his Soviet-approved values, rock music is the provenance of capitalists.

The most striking and systematic use of rock in Joaquin Murieta, however, comes inextricably tied to the character of Death. After the appearance of Joaquin's Star - his guiding force and, it seems, guardian angel - we see and hear Death for the first time (around 22:30 in the film version). In contrast to the Star's tuneful aria, his almost-spoken vocal delivery has no real melody to speak of and is reminiscent of the lower ranges of Capitan Beefheart's gravelly tessitura. The lyrics warn of the dangers of "following the Star without looking under their feet," foreshadowing that "the path to the Star is littered with hundreds of heads." His rhythmic repetition at the ends of certain phrases ("в пропасть упадет, в пропасть упадет!”) recalls Jesus Christ Superstar's accentual irregularities (as in on the words "Nazareth, your famous son..." in Judas's opening number, "Heaven on Their Minds"). Each time Death appears subsequently, his tuneless assertions are underscored with the same frantic percussion and driving bass ostinato. Each of his appearances is also marked by some sort of vocal anomaly, whether it is the funk/soul-style grunts in "Death's Aria" or the distorted, rhythmical "hee-hee-hee, ha-ha-ha, ho-ho-ho" in the aforementioned "Budet zavarukha," where he predicts a time when "son and daughter will fight" and "mother will rob daughter." Although such vocal manipulations can occur as borderline comical, such as in VIA Ariel's "Komnata smekha," or surrealistic, such as in the Beatles' "I am the Walrus," in this context the distortion takes on a morbid affect that is not subject to human rules. ${ }^{131}$

The narrative apex of the opera, Teresa's rape and murder, is marked by the boogiewoogie tinkling accompanying the white gold-panners' unexpected appearance in her home. The juxtaposition of this innocuous, almost good-natured music, and the horrible crime that is to occur ("I'll need help for this business... We'll help you, get in line, boys!") comes off as jarring and unsettling, eventually giving way to a hectic rock beat reminiscent of a Led Zeppelin jam. As Joaquin returns and vows revenge, mourning Teresa's death,

130 Schmelz, 74.

131 Ariel', “Komnata smekha," Kazhdyi den' tvoi, Melodiya, 1982. The song can be heard here: https:// www.youtube.com/watch?v=jmA1EKrMTAI. 
singing stops in the show altogether and harsh, driving rock takes over. In the shoot-out that follows (Chileans vs. Americans), the distorted ascending guitar riff from the overture returns again, identifying itself as the revenge motif. As opposed to the mixed-meter deviations of Death's songs, Joaquin's revenge music is in $4 / 4$, stable and grounded in its destructive certainty. Interspersed with quiet, poignant moments of the Chile theme, we see Joaquin's band slaughtering the Americans - and vice-versa - to this unrelenting beat. After the bloodbath calms down, we hear Death's final aria (again in an irregular rhythm), where he breaks his previous monotone declamation style and sings of "red fountains" of blood in a dramatic, soaring voice more reminiscent of Webber's Judas than any Soviet estrada performer. This is not the golden voice of Orpheus; it is the hoarse screech of Death - and in some ways, it gets the final word.

Fig. 6: L-R, Aleksei Rybnikov, director Mark Zakharov, poet Andrei Vozensenskiy, and performer Nikolai Karachentsov in 1981

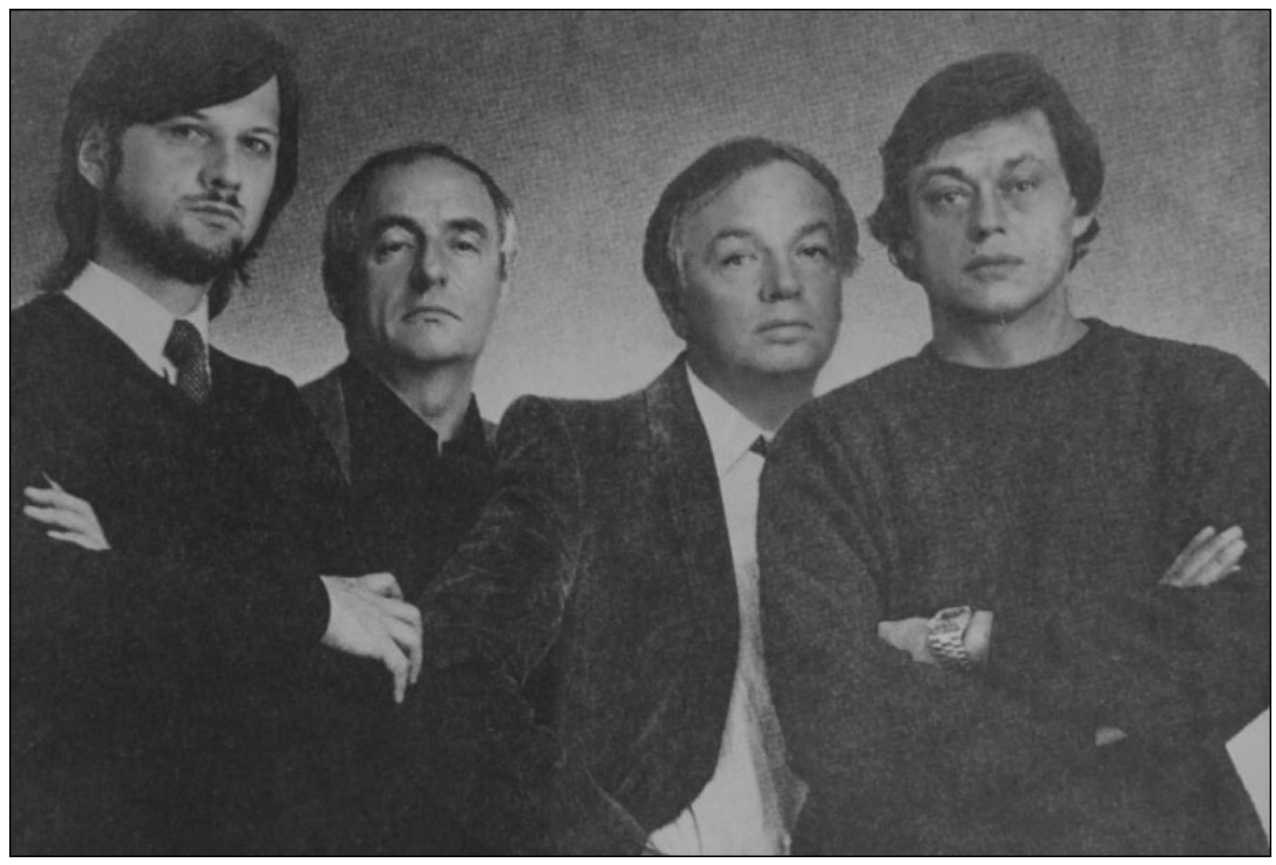

Despite the neat "good Chileans versus bad Americans form of the story," as well as Rybnikov's avoidance of the term "rock opera," Joaquin Murieta still encountered bureaucratic meddling that reminds us of Zhurbin's experience. Librettist Pavel Grushko recalls the show being banned - a mythological eleven times! - before finally premiering in May 1976 at the Lenkom Theater. ${ }^{132}$ Yet the public had already been primed by seeing

132 Guzeeva. 
rock opera on the Soviet stage, and Joaquin grew to enjoy enormous popularity, just like its predecessor. As we have seen, a film version was also authorized, and the Rybnikov/ Zakharov creative team went on to produce another - this time thematically Russian rock opera based on the work of Soviet poet Andrei Voznesenskiy in the early 1980s. Their chosen style proved to be enduringly popular once initial obstacles were overcome. Even despite its potential taboos, ultimately, a scripted opera was less unpredictable than a rock concert, and therefore "easier to restrict within moral and ideological bounds." ${ }^{133}$ Taking this into account, Soviet rock opera was very much a product of its environment, and grew to be viewed as a contribution to music history under the aegis of the Third Direction.

\section{Conclusion}

Rock opera's appearance in the Soviet era of "Stagnation" may still seem somewhat anomalous. But as St. Petersburg historian/journalist Lev Lurie put it:

The year 1975 was a safe, calm time. Oil prices were high. Salaries were increasing. The state was building houses, apartments, and metro stations... The powers that be allowed previously forbidden things to come to fruition. The appearance of the rock opera Orpheus and Eurydice in this leisurely, yet stagnant environment was no accident. ${ }^{134}$

Yet as we have seen in our outline of the show's history, even in this relatively peaceful time, composers and producers were obliged to carefully navigate the system - preferably with friends in high places - in order to achieve anything genuinely novel.

Russian musicologist A. Tsuker defines rock opera as a fundamentally multifaceted phenomenon: "The principle of 'poly' functions on all of [rock opera]'s levels, allowing us to speak of the polyvalence of its plots, dramaturgy, genre status, and stylistic features." 135 This becomes immediately evident in composers' and librettists' traditional choices of historical source (such as Greek myth, for example) as a rock opera's subject. Tsuker further explains the inherent duality in such decision-making, which allows for a universal appeal, yet is couched in modern language. He cites Jesus Christ Superstar as an archetypal example:

On one hand, the authors' turn to an evangelical plot allowed them to widen the range of associations, to imbue the narrative with high tragedy, and raise it to a level of eternal, universal impact - which was also aided by parallels with Bach's Passions. On the other hand, they seriously modernized the known story, bringing it as close as possible to the understandings and values of modern man. This [rock] opera reflected the spiritual search

133 Yngvar Steinholt, Rock in the Reservation: Songs from the Leningrad Rock Club 1981-86 (Larchmont, NY: The Mass Media Music Scholars’ Press, 2005), 24.

134 "Orfei i Evridika."

135 Tsuker, 170. 
of the Western youth in the " 60 s and '70s, carrying hippy ideology, and evoking very direct parallels with the social atmosphere and specific ideas of that movement... No matter which rock opera we examine, we see everywhere a similar parallelism and duality of content, connecting within itself the universe and daily life, the philosophical and the social, balancing between modernized eternity and the symbolic present. ${ }^{136}$

This same state of affairs can be seen in both of the operas examined in this article. Zhurbin's Orpheus is a modern rock singer dealing with the complexity of twentiethcentury life - yet he faces the age-old question of fame's ultimate price. Even in Rybnikov's historical show, the echoes of Joaquin Murieta's tragic fate are "preserved within folk memory and embellished with fantasy," and "have for a long time embodied eternal human values." ${ }^{137}$ In Rybnikov's rock opera - even more clearly than in Neruda's cantata "heroic personalities are larger than life. The [original] fable is stripped of many details and specifics, concrete circumstances are generalized, and the symbolic personages of Star and Death come out, giving the flavor of Greek myth/opera." ${ }^{138}$ This is where theater, estrada, and rock meet, each lending its most powerful qualities to affect the Soviet observer in previously unknown ways.

In a retrospective discussion of Soviet "rock music" during the late 1980s, Rybnikov divided the evolution of Russian rock into three stages. The first was amateur and largely derivative, when Russian "beat-groups" sang in English and took their cues from foreign bands such as The Beatles. The next stage both summarized those early efforts, and turned toward something more individualistic, such as the folk-rock of VIAs Ariel' and Pesniary. The third and final phase - which coincided with the composer's post-perestroika interview - marked a time when it was "no longer necessary to speak of rock music, but of rock poetry and rock thinking, perhaps... if the word 'rock' means anything at all."” 139 He goes on to explain:

After all, more often than not, we take [the word "rock"] to mean something incisive, catchy, and directly affecting the soul of your peers. It means sharing our pain openly, while breaking the framework and blinders of [state-run] radio and television, which have severely limited what is possible. ${ }^{140}$

This definition of "rock" as something with a particular communicative intention (rather than any specific technical qualifications) rings especially true in Soviet society. When officials objected to the title "rock opera," it was the presumed political intent behind such terms that shocked more than any aesthetic gestures. This is why the Third Direction

\footnotetext{
136 Ibid., 170-171.

${ }_{137}$ Ibid., 173.

138 Ibid.

139 Aleksei Rybnikov, “Rok-muzyka: prodolzhenie razgovora,” Muzykal'naia zhizn' 13 (6 May 1987): 5.

140 Ibid.
} 
aimed to reconcile not only disparate musical trajectories, but their disparate audiences as well.

Ultimately, rock opera as it is understood in the West was unexpectedly well suited to the USSR because of the Soviet penchant for theatricalization, as well as the Third Direction's preoccupation with blending popular and classical styles. This put estrada songwriters such as Zhurbin and Rybnikov in a unique position - classically trained composers who undertook the "socially responsible" task of writing popular music in order to both educate and enlighten the youth of their society. Zhurbin's first effort opened the door for more and more reassessment of popular music under the aegis of late socialism. As Peter Schmelz writes, "Orpheus and Eurydice becomes an ideal indicator of both late socialism and late socialist realism; its reception illustrates the cracks that were beginning to appear - and were often allowed to appear - in official orthodoxy." ${ }^{141}$ Joaquin Murieta followed in its footsteps, increasing the potential musical provocations. The mid- to late 1970s were a unique time in Soviet history: a period of trepidation, yet also of creative openings. The experiences of Rybnikov and Zhurbin help to show how artistic agents could operate under Brezhnev, claiming both authorship and agency, in liminal states between the official and unofficial.

\title{
Bridging Deep Chasms: The Soviet Third Direction in Aleksei Rybnikov's Rock Opera The Star and Death of Joaquin Murieta
}

\begin{abstract}
Rock opera in the Soviet Union was a phenomenon with obviously Western roots yet inextricably tied up with and enabled by homegrown players and policies. Aleksei Rybnikov's The Star and Death of Joaquin Murieta (1976) is an early example of the merging of academic and popular music desired by the Composers' Union. An examination of the genesis, production, and reception of this Soviet rock opera will shed light on the philosophical and compositional movement called "The Third Direction" - and why it was considered desirable.
\end{abstract}

\section{Překlenutí hlubokých propastí: Sovětský Třetí proud v opeře Zvezda i smert' Khoakina Mur'ety skladatele Alexeje Rybnikova}

\begin{abstract}
Abstrakt
Přestože je rocková opera spojována zejména s autory “západní” provenience, uvedený žánr významným způsobem zasáhl rovněž do tvorby skladatelů v Sovětském svazu. Dílo

141 Schmelz, 67.
\end{abstract}


Alexeje Rybnikova Zvezda i smert' Khoakina Mur'ety (1976) je jedním z prvních příkladů spojení akademické a populární hudby v dané zemi; spojení, které odpovídalo dobovým požadavkům instituce Svazu skladatelů. Reflexe vzniku, produkce a recepce uvedeného díla objasní filozofická a kompoziční východiska hnutí označovaného jako Třetí proud, rovněž důvody oficiální poptávky hudby tohoto typu sovětskými kulturně politickými institucemi.

\section{Keywords}

Estrada; Pablo Neruda; rock; rock opera; popular composers; Russia; Rybnikov; Soviet Union; theater; Third Direction.

\section{Klíčová slova}

Estráda; Pablo Neruda; rock; rocková opera; populární skladatelé; Rusko; Rybnikov; Sovětský svaz; divadlo; Třetí proud. 